\title{
Liberalism and the Defence of Political Constructivism
}

Catriona McKinnon

Palgrave, Basingstoke, 2002, ix+386pp.

ISBN: 0742521788 / 0742521796.

Contemporary Political Theory (2004) 3, 115-117. doi:10.1057/palgrave.cpt.9300102

Contemporary philosophical liberals believe that the political principles regulating their liberal societies need justifying to all those who are subject to these principles. If they are to accomplish this task successfully, liberals must avoid building liberal ideals into the very process of justification and they must also properly acknowledge the permanence of deep diversity in the value beliefs that people hold. This much is familiar Rawlsian territory. There is an interesting question as to why the political needs justification and whether it requires a different kind of justification from what is not political. However, let us leave that question to one side. Catriona McKinnon, in this important and challenging new book, shares Rawls' view that the task of political justification is best accomplished in constructivist fashion. Constructivism asks what principles would be accepted by ideal persons, conceived as practical reasoners together discharging the responsibility of agreeing principles of justice to regulate their shared society. The 'construction' is two-fold — of the persons who confront the problem of justice and of the principles they then agree upon. There are familiar worries about constructivism. Whether or not, for instance, it is circular or question-begging by assuming in its characterization of the constructors and the circumstances of their construction the very principles it aims to see constructed. Or, again, how principles agreed hypothetically by ideal persons could motivate actual individuals in real political circumstances. However, again, let us leave these questions to one side.

The question that does press is why such agents of construction would, when faced with the fact of ineliminable pluralism, be motivated to tolerate the differences between them and use a common 'public reason' to agree upon 'substantive principles of justice'. McKinnon outlines and rejects two familiar answers: that individuals would believe that a shared reason 'underdetermines' value beliefs, and that they would believe that the exercise of judgement is subject to 'burdens' that make disagreement inevitable. Both strategies are, she thinks, too demanding. Each person would have to accept the same explanation of diversity, and, crucially, in accepting such an explanation, acknowledge that their own value judgements are either possibly underdetermined by reason or subject to burdens that may render them false. Could 
people have diverse reasons as to why there is diversity (the 'many flowers' view)? Yes they could, but only if there is also some ground for all being motivated to accept toleration and public reason. This, McKinnon thinks, is given by self-respect. The idea is simple. Everyone, whatever her value judgements, has a reason to value self-respect and thus, crucially, its social bases. The core of McKinnon's book is a definition of a minimally demanding version of self-respect and of its social bases so as to justify substantive liberal principles of justice. People must value the same kind of self-respect even if they do not value the same kinds of lives as give them self-respect. McKinnon's project stands or falls on whether she can show this. She defines self-respect as congruence - between how an individual thinks of herself and what she does or achieves - and nonsubservience. A subservient person does not think she is owed a justification by others of what they expect her to do. The condition of nonsubservience is needed to rule out the case of somebody who is successful at achieving what others, without justification being required, demand of her. A Stepford Wife is McKinnon's nice example.

Now, of course, one way to exclude the Stepford Wife kind of example is to insist that the lives individuals want successfully to lead must be lives they are right to want to lead. McKinnon rules this out on the grounds that this would mean that individuals could respect themselves without knowing as much. It could also mean that individuals are in a state of blissfully ignorant and thus false self-respect. She may be right that self-respect is essentially self-regarding. However, consider that individuals do not want just to lead the life that they believe is the right life, but rather the life that they are in fact right to think is the right one. No one wants to live a lie. What may enter at this point is the endorsement constraint beloved of liberal critics of perfectionism, namely that a life goes well only if it goes well by the lights of values and beliefs that the individual concerned actually embraces. However, this broaches very broad and substantive matters of dispute between the liberal and her critic.

Consider - from the other side as it were - the very different claim that many individuals in contemporary liberal societies value lives that violate the nonsubservience constraint. They do think they flourish by conforming their behaviour to the dictates of a tradition, or a religion, or an authority, and which, they think, do not need justifying to them. Could it be that the requirement of nonsubservience ties the value of self-respect too closely to the recognizably liberal ideal of personal autonomy, one that some nonliberals at least in liberal societies do not endorse?

A review of this length cannot do justice to the range of arguments within what is a rich, complex, and stimulating book. A final chapter on the social bases of self-respect that discusses the value of group membership and distributive justice merits a review in itself. The book is to be commended for the rigour and sophistication of its approach. It is above all estimable for the 
illumination it casts on the value that McKinnon is right to think is at the very heart of Rawlsian liberalism: self-respect and its social bases. Any subsequent treatment of this value must now make reference to McKinnon's account.

David Archard University of St Andrews. 